Winick, Amber. "Houze, Rebecca. 2015. Textiles, Fashion and Reform in Austria-Hungary Before the First World War - Principles of Dress. Farham, Surrey and Burlington, VT: Ashgate. 384 pp. 79 col. Plates. 109 b. and w.

illus.." Hungarian Cultural Studies. e-Journal of the American Hungarian Educators Association, Volume 10

(2017): http://ahea.pitt.edu DOI: 10.5195/ahea.2017.294

\title{
Houze, Rebecca. 2015. Textiles, Fashion and Reform in Austria- Hungary Before the First World War - Principles of Dress. Farham, Surrey and Burlington, VT: Ashgate. 384 pp. 79 col. Plates. 109 b. and w. illus.
}

\author{
Reviewed by Amber Winick*, Independent Design Historian
}

For their 1867 coronation as emperor and empress of the newly established AustroHungarian Empire, the Austrian-born Franz Joseph I and his wife Elizabeth, affectionately known as Sisi, dressed to politically impress. The emperor wore an eleventh-century mantle and crown of Szent István, (otherwise known as Saint Stephen, patron saint of the Magyars). The empress, meanwhile, wore a sumptuous ball gown inspired by the Hungarian folk dress most closely associated with the Transylvanian peasantry, designed in Paris by the renowned couturier Charles Fredric Worth. The task of their clothing was threefold: to signify the Austrian Empire's unity with Christian Hungary, to mitigate racial tensions, and to project an image of inclusivity and worldly cool. Hiding the colossal tensions and losses that lurked just underneath this majestic façade, their garments conjured an image of a peaceful, respectful relationship between the two nations that were just then undergoing Ausgleich or Kiegyezés, meaning the Compromise re-establishing the sovereignty of the Kingdom of Hungary as separate from and no longer subject to the Austrian Empire. For this multiethnic and multilingual region undergoing enormous change, dress was a highly symbolic and politicized affair, just as it was for the emperor and empress. [Please see C. M. VanDemark: https://doi.org/10.5195/ahea.2016.254.]

During the turbulent years of the Austro-Hungarian Dual Monarchy (1867-1914) and the subsequent shift to modernity, dress and textiles expressed and sometimes even drove issues of national identity and design for modern life. From the political pageantry of the emperor and empress's coronation, to the significance of military regalia or rurally produced embroideries, to period fashion magazines claiming Vienna as the next fashion capital (promoted as a new, more exotic Paris to the East), fashion and textiles were a vital and metaphorically rich part of life in Austria-Hungary. Rebecca Houze's impressive book, Textiles, Fashion, and Design Reform in Austria-Hungary Before the First World War-Principles of Dress explores the intersection between the history of design and Central-European studies, offering a reading of fin-de-siècle culture in the Austro-Hungarian Monarchy with costume and textiles at its heart.

*hello@amberwinick.com

(cc) Br

ULLS D-Serle
New articles in this journal are licensed under a Creative Commons Attribution 4.0 International License.

This journal is published by the University Library System of the University of Pittsburgh as part of its D-Scribe Digital Publishing Program and is cosponsored by the University of Pittsburgh Press 
Winick, Amber. "Houze, Rebecca. 2015. Textiles, Fashion and Reform in Austria-Hungary Before the First World War - Principles of Dress. Farham, Surrey and Burlington, VT: Ashgate. 384 pp. 79 col. Plates. 109 b. and w. illus.." Hungarian Cultural Studies. e-Journal of the American Hungarian Educators Association, Volume 10 (2017): http://ahea.pitt.edu DOI: 10.5195/ahea.2017.294

By looking at the unusual and widespread preoccupation of Austro-Hungarian culture with embroidery, fabrics, clothing and fashion, Houze's exhaustive archival research tells us the intersecting stories of makers, wearers, artists, critics, and the various people whose lives were touched by these designs. In doing so, the author illustrates the momentous role played by fashion and textiles in Austro-Hungarian social and political life during this turbulent era. Cutting through disciplinary barriers, Houze draws parallels among embroidery, clothing, architecture and painting, and thus posits an interdisciplinary analysis of the ideas and practices related to all of them. Not only does Houze draw on contemporary theorists, but she also probes period attitudes relating to gender, industry, ethnography and national identity. Focusing on the fifty-year duration of the Dual Monarchy, Houze creates a textile and fashion-centric narrative with which to discover a few of the stories - some familiar and others left out of the dominant accounts - that drove modern Austro-Hungarian history. While Houze presents a dizzying array of patterns, designers, artists and makers, I craved a more formal and in-depth analysis of a few specific objects. Nevertheless Houze herself admits that such analyses are not part of her scope and her book lays impressive groundwork for anyone who might be interested in focusing further research into a particular artist or object. Houze also beautifully describes the rich and layered intellectual and artistic environment that gave birth to so many fascinating and meaning-laden designs. While her focus is not always equally balanced between the two halves of the AustroHungarian Empire, each of her chapters are expertly researched and could easily stand alone as independent articles. As a whole, the book is a lively account of the fluctuations and transformations of ideas between cities and regions, and the national influences and tendencies that impacted them.

Houze's study is many-sided and complex, as reflected by the meandering chronological and thematic structure of her book. From the onset, the author explains the central theory the book is woven around, which is Gottfried Semper's mid-nineteenth century theory of Bekleidungsprinzip, or "principle of dress" (28). In his 1851 book The Four Elements of Architecture, Semper posed the question of what assemblies and systems were universal in all structures, and decided that textiles were one such system. Following this realization, Semper drew a parallel between the ornamentation of buildings and that of people's clothing. He described both clothing and buildings as material covers and conceptual signifiers; both could cloak or disguise, display and transform, conceal and define the objects beneath them. For Semper, textiles were a basic and necessary tool for delineating space and central to humanity's earliest artistic strivings for symbolic ornamental motifs.

Semper's theory and metaphorical language surrounding clothing saturated late nineteenth- and early twentieth-century debates on architecture and design reform in Habsburgruled Central Europe. Viennese architect Otto Wagner, for example, drew parallels between the eclectic historicist buildings on Vienna's grand Ringstrasse and costumed carnival goers. Wagner was not opposed to fashion in and of itself, but rather to the antiquated nature of the ornamental dress of such buildings. Other Viennese architects and followers of Wagner, such as Adolf Loos and Josef Hoffmann, freely employed metaphors of dress in their architectural styles and philosophies on art, craft, ornament, and even fashion itself. Loos's essay "Ornament and Crime" advocated smooth and clear surfaces in contrast to fin-de-siècle lavish decorations and also to the more modern aesthetic principles of the Vienna Secession (28). Loos believed that the 
Winick, Amber. "Houze, Rebecca. 2015. Textiles, Fashion and Reform in Austria-Hungary Before the First World War - Principles of Dress. Farham, Surrey and Burlington, VT: Ashgate. 384 pp. 79 col. Plates. 109 b. and w. illus.." Hungarian Cultural Studies. e-Journal of the American Hungarian Educators Association, Volume 10 (2017): http://ahea.pitt.edu DOI: 10.5195/ahea.2017.294

modernist architect should not participate in the economy of fashion, which he thought shortened the lifespan of useful objects or dwellings. Loos himself dressed in suits that mirrored his buildings: stripped-down, with as straight and classic a line as possible. As a co-founder of the Wiener Werkstätte, Hoffmann, by contrast, favored a more ephemeral style of surface dressing, believing that architects, applied artists and painters all had the right to fashionably express themselves with spontaneity, creativity and dynamic change.

With such aesthetic foundations and theories as background, Houze describes the culture of applied-arts reform in the late nineteenth century and the many efforts that were made to collect, preserve, and exhibit locally made textiles and needlework as ethnographic artworks. She argues that Austria's program to revive and reform needlework in the 1870s and 1880s were largely imperialistic, as museum curators and educators believed that the needlework industry would gain from bringing the provincial regions into Austria's booming industrial and economic center. This center, in turn, would gain from its (re)turn to so-called true, indigenous crafts. Founded in various regions of the Empire, the embroidery schools (Fachschulen für Kunststickerei) were intended to be beneficial to the economy by boosting the production of quality Hausindustrie goods, while simultaneously helping society, on a smaller scale, by providing employment to peasant and lower-class women. With threads of philanthropy, commercialism, ethnographic interest and nationalism all bound together as textiles, the resulting weavings were meant to unify the Empire and promote various strands of its culture as one unified whole.

Yet Hungarian artists and craftspeople treated the Fachschulen that taught craft with suspicion even though Hungarians within the Dual Monarchy were highly interested in identifying and promoting the national identities of their individual ethnic groups. In the Hungarian context, folk embroidery took on a rarefied, almost spiritual significance. Magyar designers, critics, ethnographers and historians regarded embroidered textiles as conduits for connecting Hungarians to the spirit of their motherland and for distinguishing their own group from all others. Meanwhile, both Austrian and Hungarian identity could not exist separately from their imperial frame, which encompassed all the groups that inhabited the territory ruled by the emperor. Even for those less familiar with the story of the Hungarian search for a new native language of form, as Ödön Lechner, the grandfather of Hungarian architecture preached, Houze's textile-centric narrative is a fascinating account of the social and political issues surrounding iconic Hungarian design and the search for national style (110). The modernist folkart revival in Hungary, which included painting but also architecture, ceramics and furniture, owes a great deal to textiles and embroideries, and it is not by chance that embroidered patterns like the iconic Hungarian stylized tulip came to stand for the nation. Even today, embroidery patterns have a true staying power; they may have originated in the seventeenth and eighteenth centuries, but they were translated from the Baroque by the hands of great-grandmothers and would eventually decorate the surfaces of chic urban buildings and other modernist objects.

Providing insight into artistically oriented nationalism is one of the main strengths of Houze's book. On the one hand, Hungarian designers like Mariska Undi, Ödön Lechner, Károly Kós and Aladár Körösföi-Kriesch (who adopted the name of the Transylvanian village Körösfö in a romantic gesture of national devotion) viewed their commitment to the folk as stemming from a sense of pride and empowerment, along with a considerable dose of resistance to the 
Winick, Amber. "Houze, Rebecca. 2015. Textiles, Fashion and Reform in Austria-Hungary Before the First World War - Principles of Dress. Farham, Surrey and Burlington, VT: Ashgate. 384 pp. 79 col. Plates. 109 b. and w.

illus.." Hungarian Cultural Studies. e-Journal of the American Hungarian Educators Association, Volume 10 (2017): http://ahea.pitt.edu DOI: 10.5195/ahea.2017.294

Hapsburg rule. Austrian critics and curators, on the other hand, were far less appreciative of the Hungarian style, which they associated with a provincial nationalism. The Austrian critic Alois Riegel had no illusions about saving the folk art of the past, nor was he willing to accept the perspective that folk art had a pivotal role in the formation of the nationhood of the numerous peoples of the East, Central and Southwestern Europe. As Houze explains, "For Riegel it was unseemly to perpetuate the artificial manufacture of these traces of a primitive, possibly oriental culture, when Austria's role had long been that of gatekeeper against the East, especially during times of political or ethnic strife" (111). Houze's ability to examine objects against various and competing historical perspectives makes for a rich and layered understanding of the designed objects of the period. By presenting the dueling perspectives of the Dual Monarchy, here Houze calls attention to the competitive and transnational aspects of nationalism. The author's sensitivity to the ideas behind the designs she examines underscores how the same objects might appear completely different depending on who was doing the looking.

In addition to their standing for national and imperial issues, fashion and textiles were also permeated by questions of gender and social status. Houze provides vigorous examinations of these tensions and the ways they intersected, revealing how attitudes towards peasants, women and minorities were not only related, but also intertwined. Here, Viennese architect and cultural critic Adolf Loos's famous dictum that "Wherever I abuse the everyday-use-object by ornamenting it, I shorten its life span.... Only the whim and ambition of women can be responsible for the murder of such material" comes to mind (Adolf Loos, "Ornament und Erziehung," Trotzdem: Gesammelte Schriften; trans. Megan Brandow-Faller; Vienna: Prachner, 1997, 177). While Loos's views had never crystallized into the modernist agenda, which would subsequently be taken up by Le Corbusier (Charles-Edouard Jeanneret), Vassily Kandinsky and Walter Gropius, his attitudes created the backdrop for the modern mood in Vienna, which, despite his belittling of women's crafts, was a fertile environment for the more "feminine" aesthetic of the Vienna Secessionists. Indeed, the new style of the Wiener Werkstätte, represented by fashions on display at the 1915-1916 Modeausstellung at the k. k. Österreischisches Museum für Kunst und Insustrie in Vienna, drew its vitality from the creative combination of folk art and women's crafts that had long enlivened Central-European design reform and education.

As the social and political goals of the women's movements intersected with the aesthetic goals of the newly formed associations of modern artists and their champions in the Viennese press, long-debated questions of the relationship between taste, economic strength, femininity and national identity in Austria-Hungary were brought to the fore. Houze's sixth chapter, "Fashion and its Discontents," takes a close look at the ways in which issues of health and reform dress collided in the service of artistic women. The debates about reform dress were closely related to discussions of the emancipation (meaning also a literal freedom of movement) of women; for example, new, loose clothing freed women from the tyranny of the corset. Yet designers of reform dresses, many of whom were artists experimenting with fashion by dressing their wives, considered women as objects to be beautified and decorated rather than as individuals with power and agency to dress themselves. 
Winick, Amber. "Houze, Rebecca. 2015. Textiles, Fashion and Reform in Austria-Hungary Before the First World War - Principles of Dress. Farham, Surrey and Burlington, VT: Ashgate. 384 pp. 79 col. Plates. 109 b. and w.

illus.." Hungarian Cultural Studies. e-Journal of the American Hungarian Educators Association, Volume 10 (2017): http://ahea.pitt.edu DOI: 10.5195/ahea.2017.294

The second part of the book is impressively documented and highly enjoyable, presenting an original analysis of the production of artistic textiles and fashion reform in turn-of-the-century Vienna. However, while the first part of the book emphasizes the flow of ideas and aesthetics between both halves of the Empire, the second part is heavily weighted toward the Viennese perspective. While the author rightfully treats Vienna, the city of Sigmund Freud, Gustav Klimpt and Egon Schiele, as a modernist lightning rod, Hungary is perhaps unintentionally left situated as a pre-modern backdrop to Austria's innovations. While Houze gives the Gödöllö artist colony a mention in relation to artistic dress, she could have discussed the group further, particularly in relation to Mariska Undi's considerable contribution to modern Hungarian textiles. Likewise, Anna Lesznai, Józesef Ripple-Rónai and János Vaszary were members of the Hungarian Art Nouveau in their own right and seriously engaged in textile design of the time. Houze herself is forthright about the limitations of the narratives she chooses to tell; nevertheless, given her detailed methodological framework, it would have been an excellent opportunity to expand her scope to include at least some of the many Hungarian designers and artists who pushed the boundaries of fashion and textiles after the turn of the twentieth century.

Throughout the book, Houze enriches her arguments with an impressive array of material vestige, from folk-art objects to industrial and interior designs, fashion magazines and exhibition reviews to World's Fair maps, museum lectures, ethnographic collections and feminist journals. Along the way, the author also shines a spotlight on a network of important women writers, teachers, practitioners and patrons and on the complex debates their work elicited with regard to ideas about art and industry, national identity, the primitive and the urbane, tradition and modernity. All this makes Fashion, Textiles and Design Reform in Austria-Hungary Before the First World War so much more than the title suggests. Houze's multi-dimensional exploration provides insights into the social and national relationships that made the Empire so intellectually lively and artistically fruitful. Semper's theory of textiles as objects that could both separate and connect is an apt metaphor for how dress and textiles illuminated the power dynamics of AustroHungarian Empire. Indeed, the textiles produced throughout the region defined relationships, delineated identities and marked boundaries. But like textiles themselves, these relationships and identities were also porous, changeable, and were often stitched together over time. Houze investigates this complex tapestry with impressive sensitivity and scope, making a momentous contribution to the study of cultural history in Austria-Hungary, as well as to our understanding of the social aspect of textiles, design reform and the status of design and decorative arts within the modernist era. 